\title{
Radio-Active Luminous Paints
}

\author{
Substances That Are Being Found of Value During the War \\ By Arthur H. J. Keane
}

SinCE the commencement of the present Great Wa there has been a rapidly increasing demand for such luminous articles as radium watches, luminous cømpasses et hoc genus omne, more especially for use in the artificial light are not available--and, if they were their use would be accompanied by serious risks. Already use would be accompanied by serious risks. Already
since the beginning of the seventeenth century certain since the beginning of the seventeenth century certain
substances have been kn॰wn, such as phosphorus for substances have been kn॰wn, such as phøsphorus for
instance (which possesses the pøwer of shining in the instance (which possesses the pøwer of shining in the
dark), pr vided they have first been exposed t॰ daylight

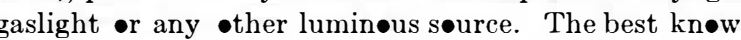
of these preducts is Balmain's Luminøus Paint, cønsisting of a sulfurous combination of calcium made with the aid of a high degree of heat. As at the present time, it was alsø ence used frequently for painting the curbstones at dangerous curves, and in dark positions, se as t• render them visible at night. This practice was as to render them visible at night. This practice was
revived this winter in London where, in the darkened streets, they often proved of very great service. The luminøsity of such substances may be explained as f $\bullet$ lows: Phosphorescence takes place if the sulfide of an alkaline earth (calcium, strøntium or barium), or of zinc, be reasted with traces of certain metals and with a fusible addition, mostly in the form of a colorless salt. As foreign metal, copper, zinc or bismuth is more especially used, an extremely small proportion of which is added to every $\bullet$ unce $\bullet$ sulfide. Under the influence $\bullet$
light these substances thrøw $\bullet$ ff electrons, or negatively light these substances thr $\bullet$ off electrøns, or negatively
charged ultra atømic particles, while the molecules charged with positive electricity remain behind and form positive ions. As søon as the exposure to light ceases reincorporate themselves with the ions. Due to the løw electric conductivity of the sulfides this, høwever -nly takes place with excessive slowless, and the radiation of light is thus produced by the reunion of the electrons with the ions.

Such phøsphørescent substances, høwever, are n॰t suitable for use in the field, as they always require prior exposure to light which, in the case of a watch that is always carried in the pocket, can easily be for gotten. A further drawback lies in the fact that, afte exhausted that it n॰ lønger exerts any useful effect up॰n the eye. This is especially the case with those phosphoruses which give a very strong light immediately phøruses which give a very strong light immediately
after exposure, such as sidot blend (crystallized zino after expo:
sulfide).

In the year 1899 B॰cquerel found that radio-active preparations diffuse a weak light. Furthermore, he found that radio-active substances were alse able to impart light-giving properties t• •ther bødies. Thus, for instance, a diamond, when placed close to them, gives •ff a white light; this is als• a process for differentiating between genuine stones and imitations. The luminosity of these substances is caused by invisible luminosity of these substances is caused by invisible
rays which emanate from the radio-active substances. rays which emanate from the radiø-active substances.
The term radiø-active is $\bullet$ ne which is applied t• bodies which, in contradistinction to the chemical elements

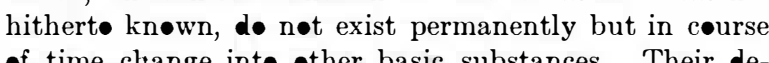
-f time change inte other basic substances. Their dethe irradiation of rays of light. These rays consist

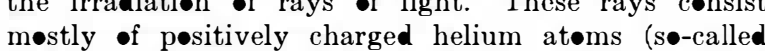
møstly of pøsitively charged helium atøms (sø-called
alpha particles), which are thrøwn $\bullet$ ff with a velocity of abøut ten thøusand miles per second, and they comof about ten thousand miles per second, and they com-
pose about 90 per cent of the total radiation. Other substances, on the contrary, send out beta rays, nega tive $\bullet$ electrons. In spite of their great velocity, which is almost equal to that of light, yet their energy amount to about 5 per cent of the total radiation. About the same is the action of the last rays, the gamma rays, which-in contradistinction to the tw• preceding group - de not consist of single particles but are very short ether waves like the R•entgen rays.

Now the alpha rays are those which have an effect up॰n certain substances similar te that of light, i.e. they split up the molecules int• ions and electrons, the reunion of which is accompanied by the irradiation of especially in these cases, t• add sidet blend to the radieactive substance because, as we have already seen, this blend has the strøngest effect in producing the radiation of light. That this light søon dies away is, here, nø taken inte consideration as the sidot blend •wing t• the

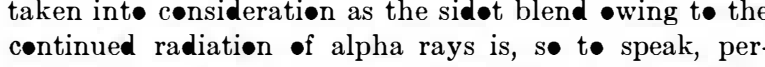
manently re-excited by the admixture of the radie active substance.
A radio-active luminøus paint differs, theref $\bullet$ re, frøm the formerly known phosphorescent substance $e^{1}$ in the fact that it does not require any prior exposure tø light. On the contrary the excitement or action is, in this case, produced permanently by the rays which are thrown off without interruption by the

contained in the luminous paint

As already remarked a radio-active substance is not

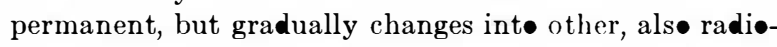
active, stuffs. Thus, for instance, radium changes inte a gaseous body (the sø-called radium-emanation) which in its turn, changes successively int॰ further sølid

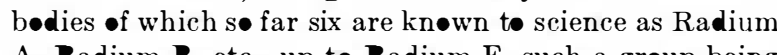
A, Radium B, etc., up t• Radium F, such a grøup being termed a "Radio-Active Family." A secend and third family are formed by thorium and actinium respectively with their products of decomposition. Due to this gradual conversion the primary, or fundamental, subgradual conversion the primary, or fundamental, sub-
stance is of course not permanently maintained. The periods of time, within which such a substance disappears, differ very considerably. Hence the semivalue periods (i.e., the time within which one-half of the substance has decomposed or "disappeared") are
1,690 years for radium, and about four days only for the radium-emanation. Mesøthørium, which is alsø used radium-emanation. Mesøthørium, which is alsø used
for clinical purposes, is $\bullet$ btained frøm the manufacture f $\bullet$ incandescent mantles and has a semi-value period of abøut five and one-half years; the radiø-thorium •btained from mesethorium, and the thorium $\mathrm{X} \bullet$ btained from the latter, have a semi-value period of tw॰ years and a little less than four days respectively. The same periøds for the actinium series are sø small, that for consideration at all.

Of the substances named radium alone possesses a sufficiently high semi-value period se that, apparently, radi-active luminous paints can only be secured by adding radium to the sidet blend. This assumption would be quite correct if the duration of a luminous paint depended merely up॰n the addition of the radioactive ingredient, and if the sidot blend remained unchanged. As a matter of fact, høwever, this is als ment" of the alpha rays, by the continued "bombardsteadily declines; this it does all the more rapidly the more powerful the excitation and the brighter the initial more powerful the excitation and the brighter the initial
light. In very strong luminøus paints a marked diminution in the power of the light is noted already after a lapse of six months. Hence it is of no use, at least in the case of a strong lumineus paint, to add radium to the ingredients; in fact it is far preferable to use meso-

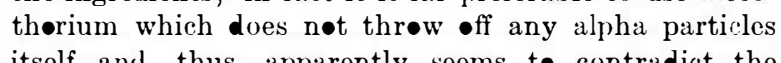
itself and, thus, apparently seems to contradict the
statements already made. Yet, in truth, pure mesethorium does not produce any light effect. N॰w technical mesothorium centains from 15 to 25 per cent radium; furthermore it alsø gradually becomes conradium; furthermore it alsø gradually becomes con-
verted into radiothorium which gives off the alpha rays and is thus highly effective. Hence a freshly preparced mesothørium luminous paint will triple or even quadruple its lighting pøwer during the first føur and •ne-half years, after which it first gradually begins to decline. thorium to the mesothørium, whereby the thrøwing •ff of rays will steadily increase during the first five years, and will not regain its initial value till after ten years; and will not regain its initial value till after ten years; after this latter period it will gradually decrease in
pøwer. But if it be taken inte consideration that the pøwer. But if it be taken inte consideration that the
action of the sulfide of zinc causes a gradual decrease in action of the sulfide of zinc causes a gradual decrease in
the lighting effect, then the initial rise in the efficiency -f the radio-active substance will tend to counteract the decrease in the radiation of light, $\bullet$ wing to the exhausluminous paint will zinc, se that such a mesothorium the first three to five years. Alsø for a further five t•

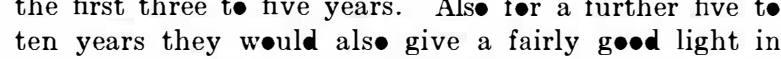
most cases, so that the useful life of such a luminous paint may be estimated at a period of ten years $\bullet$ n the average. In the case of a pure radium luminous paint the lighting pøwer begins t• decline ab initio due to the exhaustion of the sulfide of zinc, which acts as the light carrier, sø that it would become useless within this period. For very strøng luminous paints, however, the addi-

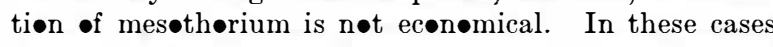
the exhaustion of the sulfide of zinc is s- strong, that the light intensity already becomes practically useless .within

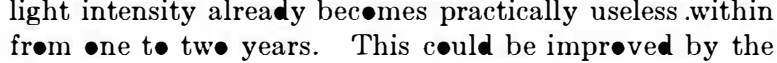
addition of pure radiothorium.

${ }^{1}$ Not all phosphorescent substances respond to alpha ray.
As the radiø-active luminøus paints cøntain abøut 1-60 milligrams of radiø-active substance t• every 100 grams of sulfide of zinc, and as a milligram of radium abøut $£ 10$ (radiø-thørium is cheaper), hence a really gøod luminøus paint must n॰t be expected to be cheap. This, naturally, gives rise to the temptation to mix This, naturally, gives rise to the temptation to mix
cheaper substances inte the paints, the principal subcheaper substances int the paints, the principal sub-
stitute being th॰rium $\mathrm{X}$; as its action, høever, diminstitute being thorium $\mathrm{X}$; as its action, høwever, dimin-
ishes by 50 per cent in 3.65 days, the admixture of this substance makes itself apparent within a very short space of time. T• determine the exact amounts of radium, mesothørium and radiothorium contained in a luminous paint is a difficult matter for the expert, and quite impossible for the dealer and buyer. T• render grams would be necessary; furthermore, as the radioactive substances are added in the form of insoluble salts, it would be necessary to chemically flux the luminous paint. These are processes which can only be carried $\bullet$ with a very well equipped laboratory while, -wing to the large quantities of the various substances required, they are very costly. The purchase of a a question of blind trust and should $\bullet$ nly be made frøm some highly reputable firm or factory whose reputation is in itself a guarantee for the goodness of the paint. in itself a guarantee for the goodness of the paint.
It is alse extremely easy to make a mistake even when merely testing the substance externally. As sidot blends belong to the se-called phosphorescent substances, and become luminous after exposure to light, hence a radio-active luminous paint which has
been exposed to day or lamplight appears much more luminøus than when it has lain in the dark for søme time. It must, therefore, first of all be placed for several hours in a dark røm or in a closed receptacle before it is pøssible to test its actual lighting pøwer. A simpler way is to expose the luminous paint for a few seconds t• dark-red light - such a lamp as photographers use in a dark chamber for instance-as the red (and more espe-
cially the ultra-red) rays will cause the phosphorescence cially the ultra-red) rays
to disappear very rapidly.

Luminous paints are mostly used in a pøwdered form, and are applied to the articles it is desired to coat with the aid of an alkaline gum-lac (acid lacs would destrøy the sulfide of zinc). This process, however, is not a practica $\bullet$ ne, as the lac can easily entirely envelop the individual grains or particles, and thus hold back and prevent the alpha particles thrown off by the radioactive substance from exerting their influence.

A coating of lac is nevertheless necessary sø as to retain the gaseous emanations which, otherwise, would escape into the surrounding air; it is precisely these emanations and their products of decomposition, as
they als mostly thrøw •ff alpha rays, which substanthey alsø mostly throw off alpha

Radio-active luminøus compounds are being more and more widely used-especially since the outbreak of the present War of the Worlds. For watches relatively weak paints suffice, but for compasses a much strønger compound must be used because, in the twilight prevailing in the epen, the eye is always adapted to the reception of a weak light effect. Especially strøng cømpounds must be used when it is desired to distinguish

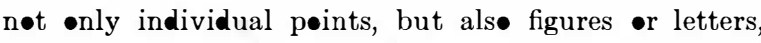
at a considerable distance. These paints are alsø largely used just now in connection with military work but,

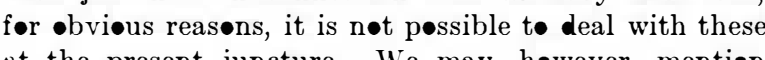
at the present juncture. We may, however, mention that very great benefit has been obtained from these paints when used at night time in the streets, darkened to prevent attacks by the German Babykillers. Luminous buttons for pedestrians, walking sticks and umbrellas with luminous handles, luminous buckles and shields for mens' hats and pølicemen's helmets, have all done good service and prevented many a collision on the pavements and loss of life when crossing the roads.

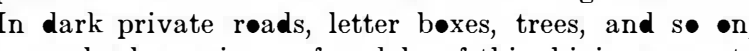
have als been given a few dabs of this shining mass, to the great gratitude and relief of those whose business pleasure compelled to wander late at night through the Stygian darkness of the London streets in War Time. Editorial Note.-C Commenting on the abøve article Laboratory, Pittsburgh, has the føllwøing to say: "As far as I kn॰w mesothorium has $\bullet$ nly been produced on a commercial scale in Germany, and while søme amøunts -f this material are being used at present, even in this
country, in the production of luminous compounds, I 
